\title{
INEQUALITIES FOR GENERALIZED WEIGHTED MEAN VALUES OF CONVEX FUNCTION
}

\author{
BAI-Ni GUO AND FENG QI
}

Abstract. In the article, using the Tchebycheff's integral inequality, the suitable properties of double integral and the Cauchy's mean value theorem in integral form, the following result is proved:

Suppose $f(x)$ is a positive differentiable function and $w(x) \not \equiv 0$ an integrable nonnegative weight on the interval $[a, b]$, if $f^{\prime}(x)$ and $f^{\prime}(x) / w(x)$ are integrable and both increasing or both decreasing, then, for all real numbers $r$ and $s$, we have

$$
M_{w, f}(r, s ; a, b)<E(r+1, s+1 ; f(a), f(b)) ;
$$

if one of the functions $f^{\prime}(x)$ or $f^{\prime}(x) / w(x)$ is nondecreasing and the other nonincreasing, then inequality $(*)$ reverses. Where $E(r, s ; a, b)$ and $M_{w, f}(r, s ; a, b)$ denote the extended mean values and the generalized weighted mean values of function $f$ with two parameters $r, s$ and weight $w$, respectively.

This inequality generalizes the Hermite-Hadamard's inequality, and the like.

Mathematics subject classification (2000): 26D15, 26B15.

Key words and phrases: Inequality, convex function, generalized weighted mean values, extended mean values, power mean, two-parameter mean, Hermite-Hadamard's inequality, Tchebycheff's integral inequality.

\section{REFERENCES}

[1] X.-Q. CAO, Inequalities of power mean for convex and concave functions, Shuxue de Shijian yu Renshi (Mathematics in Practice and Theory) 30 (1995), no. 3, 363-366. (Chinese)

[2] Y. DING, Two classes of means and their applications, Shuxue de Shijian yu Renshi (Mathematics in Practice and Theory) 25 (1995), no. 2, 16-20. (Chinese)

[3] J.-Ch. KuAng, Changyong Budengshi (Applied Inequalities), 2nd edition, Hunan Education Press, Changsha, China, 1993. (Chinese)

[4] D. S. Mitrinović, Analytic Inequalities, Springer-Verlag, Berlin, 1970.

[5] D. S. Mitrinović AND I. LACKOVIĆ, Hermite and convexity, Aequat. Math. 28 (1985), 229-232.

[6] D. S. Mitrinović, J. E. PeČARIC AND A. M. FinK, Classical and New Inequalities in Analysis, Kluwer Academic Publishers, Dordrecht/Boston/London, 1993.

[7] G. PÓLYA AND G. SZEGÖ, Isoperimetric Inequalities in Mathematical Physics, Princeton University Press, Princeton, 1951.

[8] F. QI, Generalized abstracted mean values, J. Inequal. Pure \& Appl. Math. 1 (2000), no. 1, Article 4. http://jipam.vu.edu.au/v1n1/013_99.html. RGMIA Res. Rep. Coll. 2 (1999), no. 5, Article 4, 633-642. http://rgmia.vu.edu.au/v2n5.html.

[9] F. QI, Generalized weighted mean values with two parameters, Proc. Roy. Soc. London Ser. A 454 (1998), no. 1978, 2723-2732.

[10] F. QI, On a two-parameter family of nonhomogeneous mean values, Tamkang J. Math. 29 (1998), no. 2, 155-163.

[11] F. QI AND Q.-M. LuO, Refinements and extensions of an inequality, Mathematics and Informatics Quarterly 9 (1999), no. 1, 23-25. 
[12] F. QI, S.-L. XU, AND L. DEBNATH, A new proof of monotonicity for extended mean values, Internat. J. Math. Math. Sci. 22 (1999), no. 2, 415-420.

[13] F. QI AND Sh.-Q. ZhANG, Note on monotonicity of generalized weighted mean values, Proc. Roy. Soc. London Ser. A 455 (1999), no. 1989, 3259-3260.

[14] M.-B. Sun, Inequalities for two-parameter mean of convex function, Shuxue de Shijian yu Renshi (Mathematics in Practice and Theory) 27 (1997), no. 3, 193-197. (Chinese)

[15] K. TetTAmanti, G. SÁRKÁNY, D. KRÂLIK AND R. Stomfai, Über die annäherung logarithmischer funktionen durch algebraische funktionen, Period. Polytech. Chem. Engrg. 14 (1970), 99-111.

[16] Z.-H. YANG, Inequalities for power mean of convex function, Shuxue de Shijian yu Renshi (Mathematics in Practice and Theory) 20 (1990), no. 1, 93-96. (Chinese) 